\title{
Lectura e identidad: la teoría marxista de Ber Bórojov en el contexto del judaísmo latinoamericano $(1951-1979)^{1}$
}

Reading and identity: the marxist theory of Ber Borochov in the context of latin american jewry (1951-

\author{
Dr. Leonardo Cohen Shabot \\ leocohen2000@yahoo.com \\ Universidad Abierta de Israel \\ Universidad Ben Gurión del Néguev \\ Israel
}

\section{Resumen}

El presente artículo se ocupa del papel que el pensamiento marxista de Dov Ber Bórojov desempeñó en el proceso de renovación de la identidad judía latinoamericana entre los años 50 y los años 70 del siglo pasado. Ber Bórojov (1881-1917) es el teórico que de manera más brillante y exitosa consiguió sintetizar las aspiraciones del pueblo judío a la autodeterminación nacional con las premisas más elementales del materialismo histórico. La traducción de sus obras al español, y su difusión entre sectores politizados de la juventud judía en América Latina, dio pie a que el sionismo pudiera ser insertado dentro del discurso revolucionario de este periodo. La tesis fundamental de este ensayo, consiste en que la lectura de Bórojov así como de sus diversos intérpretes, ayudó a que varias generaciones de judíos latinoamericanos de orientación izquierdista, pudieran renovar su identidad judía y su lealtad con el Estado de Israel, en un contexto en el que los movimientos revolucionarios locales resultaban sumamente atractivos.

Palabras clave: Sionismo - Marxismo - América Latina - Judaísmo - Bórojov.

\begin{abstract}
The present article examines the role of Dov Ber Borochov's Marxist thought in the reconstruction of Latin American Jewish identity between the 1950s and 1970s. Borochov (1881-1917) fashioned the most
\end{abstract}


compelling synthesis between Jewish aspirations for national self-determination and the basic premises of historical materialism. The translation of his major works into Spanish and its diffusion among the most politicized sectors of Latin America's Jewish youth enabled Zionism to participate in the period's revolutionary discourse. By reading Borochov and his various interpreters, the present author claims that several generations of leftwing Latin American Jews were able to maintain a Jewish identity and express loyalty to the State of Israel in a manner that dovetailed smoothly with local revolutionary ideological movements.

Keywords: Zionism - Marxism - Latin America - Judaism - Borochov.

Sin lugar a dudas Dov Ber Bórojov (1881-1917) fue uno de los ideólogos sionistas más brillantes y que mayor influencia ejercieron sobre generaciones de judíos sionistas en América Latina. Hasta la fecha, se considera a Bórojov uno de los pensadores que, con mayor agudeza y sofisticación, sentaron las bases para la elaboración del programa político del sionismo socialista. Como la sonrisa del gato en la noche parafraseando a Lewis Carroll- la teoría de Bórojov se dibuja aún en el paisaje, y en nuestros días jóvenes judíos la conocen y recitan en sus variantes más simplificadas, a pesar de que los textos que le dieron vida hayan dejado de editarse y las viejas traducciones hayan dejado de leerse. Pero en otras épocas Bórojov constituyó, para varias generaciones de jóvenes, una especie de canon, y sus teorías alcanzaron una significativa importancia entre sectores de judíos socialistas y sionistas de América Latina. Más que ningún otro autor sionista, más que Najman Syrkin, ${ }^{2}$ Moisés Hess ${ }^{3}$ o A. D. Gordon, ${ }^{4}$ que también fueron reconocidos como padres fundadores del sionismo obrero, Bórojov gozó de una popularidad inigualable entre círculos de la izquierda judía latinoamericana. Inclusive, puede decirse que algunos estudiosos latinoamericanos vieron en Bórojov a un teórico que ofreció valiosas herramientas de análisis para la comprensión de la cuestión nacional en general, más allá de la particularidad del problema judío. $^{5}$

El presente artículo procura indagar los motivos de la relevancia y popularidad de los postulados borojovistas entre juventudes judías de diversos países de América Latina a lo largo de tres décadas en 
las que se tradujo, se leyó, estudió y discutió el pensamiento de este ideólogo del sionismo obrero. Presentaremos primeramente un breve esbozo de su vida y obra, para después adentrarnos en el contexto en el que fue estudiado. Así, este artículo buscará rastrear la incidencia que la lectura de dichos textos tuvo en la redefinición de la identidad judía de centenares de judíos oriundos del continente latinoamericano, la gran mayoría de ellos hijos de los inmigrantes que habían arribado desde el "Viejo Mundo". A lo largo de este breve ensayo nos preguntaremos: ¿quiénes fueron los traductores e intérpretes de la obra de Bórojov al español? ¿qué recepción tuvo su obra? ¿quiénes fueron sus lectores? ¿en qué contexto social y político fue reivindicado este pensador sionista? No obstante, antes de responder a estas interrogantes, será necesario plantear de forma sintética cuáles son las directrices esenciales del pensamiento borojoviano.

\section{Bórojov en su contexto histórico. Breve nota biográfica}

El pensamiento teórico de Dov Ber Bórojov debe comprenderse en el contexto de su surgimiento, a saber, teniendo como trasfondo histórico la fase agónica del absolutismo ruso y la creciente agitación política de principios de siglo XX.

Con el ascenso al trono de Nicolás II en 1894, la situación de los judíos en Rusia se tornó precaria. El antisemitismo fue especialmente crudo en los círculos oficiales, en la prensa y en la vida pública general. Se registraron pogromos antijudíos en Shpola en 1897, en Nikolaev en 1899 y en Kishinev y Gomel en vísperas de la desastrosa guerra con Japón. El creciente temor del régimen frente una potencial revolución explica la actitud de las autoridades que alentaban estos estallidos de violencia popular. Sin embargo, con el advenimiento de la revolución de 1905, las esperanzas de emancipación de los judíos se animaron transitoriamente. Un número considerable de intelectuales y obreros judíos se integraron al movimiento revolucionario como líderes y militantes. Entre los jefes socialistas destacaron Rafael Abramovich y León Martov. ${ }^{6}$ 
Éste es el escenario histórico que le tocó vivir a Dov Ber Bórojov en plena juventud. Bórojov nació en la aldea de Zolotonoscha (Ucrania). ${ }^{7}$ Su padre, Moisés Aarón Bórojov era maestro de hebreo y militaba en el movimiento Jovevei Tzión (amantes de Sión). ${ }^{8}$ Cuando Ber Bórojov era aún muy joven, sus padres se mudaron a Poltava, en la Rusia Meridional, y ahí se aproximó a los círculos socialdemócratas, donde estudió las interpretaciones de Marx que postularon autores como Plejánov y Bugdánov. Sin embargo, Bórojov siguió sin encontrar una respuesta satisfactoria al problema del proletariado judío, que experimentaba una doble explotación -como clase y como nación oprimida- y comenzó su trabajo teórico y político para encontrar la respuesta a la cuestión desde una perspectiva marxista.

En Poltava fue donde Bórojov pasó sus mejores años, convirtiéndose en el principal ideólogo y líder del Partido obrero judío socialdemócrata, Po'alei Tzión (Trabajadores de Sión). ${ }^{9}$ La plataforma del partido, conocida como Nuestra Plataforma, es básicamente obra suya y constituye, junto con Los intereses de clase y la cuestión nacional, la base del pensamiento borojoviano sobre dicha cuestión. En estos textos, Bórojov pone de manifiesto la necesidad que tiene el pueblo judío de abandonar la diáspora para abocarse a la construcción de un Estado judío en Palestina.

Así, Bórojov participó en el Congreso Sionista que tuvo lugar en Basilea en 1905 y después retornó a Poltava, donde contribuyó a la defensa de los judíos durante los pogromos. Al igual que muchos intelectuales judíos de su generación, Bórojov se vio sacudido por los pogromos de Kishinev, a la luz de los cuales se veía con más claridad que nunca el trágico desamparo de los judíos en la diáspora. En 1906 fue el artífice de la primera convención de Po’alei Tzión. La noche en que el gobierno zarista disolvió la primera Duma, Bórojov fue arrestado, al igual que muchos otros, y después de haber pasado un periodo en la cárcel se vio obligado a abandonar Rusia como otros tantos revolucionarios.

En 1907 partió hacia un exilio que se prolongaría durante diez años en Europa y Estados Unidos. En esos años llevó a cabo una intensa labor política y científica, profundizando en sus trabajos de investigación judía. Al estallar la revolución de marzo de 1917, Bórojov no pudo permanecer más en el exterior. El partido Po'alei Tzión también demandó su pronto retorno. La tercera convención del Po'alei 
Tzión en Rusia lo nombró delegado ante la conferencia de las nacionalidades, para la que preparó dos presentaciones: "La Federación de las nacionalidades en la nueva Rusia" y "La cuestión del idioma". Su destacado conocimiento en lo concerniente al problema nacional derivó en su elección como delegado para la Convención Constitucional de la República Rusa. Durante esos días Bórojov viajaba noche y día fungiendo como emisario. En uno de estos viajes enfermó de neumonía, y murió en Kiev el 17 de diciembre de 1917, con tan sólo 36 años de edad.

\section{Los postulados del sionismo marxista de Ber Bórojov}

Tal como lo constata José Luis Najenson, una inmensa montaña de olvido se yergue sobre la obra de Bórojov a lo largo del siglo XX. Generaciones de revolucionarios ignoraron su obra, y fueron sobre todo los círculos de marxistas judíos quienes tradujeron y difundieron los escritos del pensador sionistamarxista. Las razones de este olvido, según Najenson, son de carácter ideológico. En un principio, la predominancia de la visión "cosmopolita" del problema nacional en el movimiento marxista especialmente por influencia de Kautsky- restaba importancia histórica y estratégica a la cuestión nacional, propugnando la asimilación de las minorías nacionales, aún las oprimidas. Más tarde, durante los años del culto a la personalidad, Bórojov sufrió un olvido sistemático, como cualquier otro pensador que no fuera José Stalin. ${ }^{10}$

Aun a riesgo de caer en simplificaciones, intentaremos definir los puntos cardinales de la teoría de Bórojov. El lector interesado podrá profundizar en el tema consultando algunas de las traducciones que mencionamos más adelante. En este contexto importa dejar sentado que Ber Bórojov ha sido reconocido como el pensador que de manera más sistemática consiguió sintetizar marxismo y sionismo, y que otorgó una relevancia estratégica a la cuestión nacional en la lucha por el socialismo. En su análisis, Bórojov parte de la premisa de que el materialismo histórico de Marx contiene la clave para la interpretación y la comprensión última de los fenómenos sociales, pero añade que “(...) el pensamiento progresista no ha abarcado todavía en toda su magnitud la cuestión nacional, en tanto que la cuestión social ya fue objeto de estudios profundos y prolongados" (Bórojov 1979, p. 107). En conformidad con lo anterior, Bórojov se 
ocupará en sus obras esenciales de estudiar y analizar el problema de la cuestión nacional en general, y de la cuestión nacional judía en particular, a partir de fundamentos y premisas derivadas del pensamiento marxista.

Para Bórojov existe una base materialista del problema nacional. Toda nación es una sociedad que advino bajo las mismas condiciones de producción y, además, posee conciencia de sus propios intereses políticos. Sin embargo, ello no anula la división de la humanidad en clases, en función del lugar que cada grupo de la sociedad guarda con respecto a los medios de producción. Así pues, en el fondo de la teoría borojoviana reside el principio de que el proletariado es nacional, pero su identidad nacional no está en contradicción con su carácter de clase ni con su identidad internacional.

Es cierto que en los umbrales de la Primera Guerra Mundial y en su curso posterior Lenin ("Sobre el derecho de las naciones a la autodeterminación”, Obras escogidas, 1961, pp. 615-679) y Stalin (“El marxismo y el problema nacional", 1973) introdujeron un cambio en el enfoque de la cuestión nacional, colocando en un plano destacado el "derecho de separación de las naciones", con el fin de acentuar los vínculos entre la liberación de los pueblos oprimidos y la lucha revolucionaria del proletariado. Pero en 1905, año en el que Bórojov escribe su principal obra, todavía estaban fuertemente arraigadas las concepciones cosmopolitas entre los marxistas rusos. En contraste con ello, la teoría de Bórojov viene a colocar como evidencia de la realidad objetiva el carácter nacional del pueblo judío. De esta manera, la lucha del proletariado judío por los derechos nacionales dentro del movimiento sionista no entra en contradicción con sus propios intereses de clase, ni con su aporte a la revolución en general.

Bórojov percibió que el obrero judío no sufría solamente la explotación clasista, sino también la opresión nacional, la falta de derechos ciudadanos (en la Rusia zarista, en Rumania, etcétera), el boicot económico, los pogromos. Fue también en 1905 cuando el partido judío del Bund ${ }^{11}$ se inclinó de forma definitiva por una definición nacional de la cuestión judía. Sin embargo, a diferencia de Bórojov, su programa era el de la autonomía nacional cultural y la lucha de su reconocimiento dentro del movimiento 
obrero ruso. El Bund se desligó de todo reclamo de carácter territorial y se adhirió a un nacionalismo de carácter cultural, extraterritorial. En cambio, para Bórojov, el obrero judío está interesado, más que cualquier otro, en el éxito del programa sionista, puesto que sólo esta solución le conferirá la base estratégica para liberarse de la opresión y dar lugar a la lucha de clases en el seno del pueblo judío.

El nacionalismo real, por consiguiente, es el que no oculta la conciencia de clase; se encuentra sólo entre los elementos progresistas de las naciones oprimidas. En la clase más progresista, en el proletariado organizado y revolucionario de una nación oprimida, su nacionalismo real se expresa en las exigencias claramente formuladas en su programa mínimo, y que tienen la meta explícitamente señalada de conseguir, con el restablecimiento de la nación en condiciones normales de producción, un lugar normal de trabajo y de lucha para el proletariado. (Bórojov, 1979, p. 87)

Para fundamentar desde el punto de vista marxista el sionismo obrero, Bórojov sostenía que era necesario imponerse sobre el cosmopolitismo, que agitaba la bandera de la asimilación de los pueblos débiles y el autonomismo cultural. La concentración territorial del pueblo judío en Palestina no sucedería como resultado de una maniobra dirigida sino de manera estígica, ${ }^{12}$ por encima de cualquier intención. Las condiciones objetivas de la diáspora terminarían por expulsar a los judíos de Europa, que por fuerza de las circunstancias se congregarían en Palestina, no por elección ni por razones de identificación histórica, sino porque sería el único lugar al que, de manera espontánea, les empujarían las fuerzas económicas, y a donde lograrían penetrar:

El proceso de la emigración judía a Palestina es un proceso estígico. Nace del hecho de que en los anteriores grandes países capitalistas de la emigración judía les es a los judíos cada vez más difícil pasar a las formas más altas de la producción. La necesidad de emigrar no se torna más débil entre los judíos. Al contrario. Por el hecho de que son económicamente expelidos, debido a la competencia nacional, ella se fortalece cada vez más. Por eso, los judíos se ven impulsados cada vez más a dirigirse a Palestina, como el único país semi-agrícola a donde puede emigrar la burguesía pequeño-capitalista judía. ${ }^{13}$ 
El borojovismo establece que el cumplimiento del programa sionista se llevará a cabo en dos etapas: primero se establecerá una sociedad capitalista normal y posteriormente tendrá lugar la lucha de clases. La burguesía posee en la primera etapa un papel constructor, y al proletariado le corresponde el papel liberador, es decir, la realización de la lucha política en la calle judía, así como en el ámbito internacional, a fin de asegurar el cumplimiento del programa sionista $y$, dentro de él, de las necesidades del proletariado. La independencia judía será posible sólo en el marco territorial donde los judíos constituyan la base de la pirámide social. La burguesía judía podría trasladar sus negocios de Europa al Medio Oriente, pero no sería capaz de crear una transformación tal, y por ello Bórojov afirmaba que la liberación del pueblo judío sería obra del proletariado judío, o no sería realizada del todo.

En síntesis, podemos decir que las tesis borojovianas no escapan de lo universal a lo particular. Por el contrario, apuntalan la idea de que sólo a través del establecimiento de una sociedad judía en Palestina, la lucha de clases judía se integrará a la lucha universal del proletariado mundial. Solamente a través del establecimiento de una sociedad judía que controle su propia infraestructura económica, los judíos podrán integrarse al proceso revolucionario universal. En otras palabras, que el internacionalismo auténtico pasa por el nacionalismo, no por encima de él.

\section{Traducciones al español}

Es preciso resaltar ciertas cuestiones esenciales en lo que atañe a las traducciones de las obras de Bórojov al español. Primeramente, hay que poner atención en la falta de interés por parte de círculos y editoriales de corte académico en difundir la obra de este pensador marxista. Sólo relativamente tarde en el año 1979- la Editorial Siglo XXI, en su colección Cuadernos de Pasado y Presente editó bajo la supervisión de José Luis Najenson las obras más destacadas del autor marxista. A pesar de que Bórojov dedicó una gran parte de sus escritos a analizar los fundamentos del problema nacional desde una perspectiva teórica general, sus obras en América Latina fueron traducidas y difundidas exclusivamente por judíos, y entre ellos se hallaban también sus más asiduos lectores. Los principales difusores de las 
obras de Ber Bórojov en el continente fueron los miembros de los movimientos juveniles sionistas de izquierda como la juventud borojovista de Argentina, los movimientos juveniles Hashomer Hatza'ir (la joven guardia) y Dror (libertad), así como sus subsecuentes ramificaciones. Durante el periodo que nos ocupa en este ensayo, la práctica educacional en estos movimientos en América Latina iba orientada, básicamente, a la aliyá, es decir, la emigración a Israel. Estos movimientos percibían con gran sospecha el futuro del judaísmo diaspórico y postulaban la emigración a Israel como el contenido básico de su programa educativo. Igualmente destacaban la necesidad de incorporarse a la vida colectiva en el kibutz como culminación del proyecto personal de cada individuo. De esta manera, se hacía hincapié en el hecho de que asumir una postura política de izquierdas implicaba necesariamente comprometerse con una vida en colectividad. Se trataba, en síntesis, de pensar como socialistas, hacer socialismo y vivir como socialistas.

Ambos movimientos -Hashomer Hatza'ir y Dror- surgieron en Europa Central y del Este. El movimiento Dror surgió en Polonia en 1915 (Mintz 1983). Se derivó del círculo de estudios de Tz’eirei Tzion (la juventud de Sión), cuya mayoría se integró al recién formado Hashomer Hatza'ir (Margalit, 1969, pp. 2546). Los dos movimientos preconizaban un judaísmo radicalmente secular. Ambos se expandieron por las diferentes diásporas judías, inculcando en sus miembros la voluntad de poner en práctica los principios de justicia social a través de la construcción de las colonias agrícolas cooperativas que se creaban en Palestina. Aproximadamente una década después de su surgimiento, estos dos movimientos adoptaron en diferentes grados las concepciones históricas y políticas marxistas, sin renunciar al compromiso con la idea nacional judía. Posteriormente, se difundieron por América Latina y, a lo largo de los años treinta y cuarenta fundaron sedes por todo el continente, en países como Canadá, Estados Unidos, México, Cuba, Colombia, Venezuela, Brasil, Chile, Argentina y Uruguay. Ambos movimientos se inclinaban por lo que en aquel entonces se denominaba "un sionismo maximalista y un socialismo maximalista". Esto significaba que no era posible para sus miembros concebir futuro alguno para el pueblo judío y su existencia nacional si no era a partir de una base territorial. Los dos movimientos, por tanto, bregaban por la emigración de los judíos, donde quiera que se encontrasen, hacia su tierra ancestral, la tierra de Israel. 
Por otro lado, la sociedad israelí debía de ser, a ojos de los militantes del Dror y el Hashomer Hatza'ir, una sociedad de carácter socialista, cuya base y fundamento lo constituía la experiencia del kibutz, es decir, las comunas agrícolas.

De estos movimientos se derivaron también, hacia los años sesenta, grupos de jóvenes universitarios que se organizaron sobre la misma plataforma ideológica en diferentes puntos del continente. Estos grupos se denominaban con la terminología hebrea de Jativot Tze'irot (juventudes) entre las que aparecieron la Jativá Anilewich ${ }^{14}$ en Argentina y Uruguay, Jativá Ber Bórojov, el Mapam (filial del partido obrero unificado de Israel) en México, y el FIS (Frente de Izquierda Sionista) en Chile. Estas juventudes, identificadas con partidos políticos sionistas, tuvieron una influencia importante dentro de las universidades en las ciudades donde existían colectividades judías importantes y ocuparon un lugar fundamental en la difusión de las obras de Bórojov entre círculos estudiantiles. ${ }^{15}$

Es así como los principales agentes de difusión de la teoría borojovista fueron los jóvenes universitarios. Las obras de Bórojov fueron traducidas y editadas fundamentalmente en el transcurso de tres décadas, principalmente en Argentina y Uruguay. Ciertamente, hubo una solitaria traducción al español de Isaac Arcavi, que apareció en 1936 en Buenos Aires, en ediciones Dror. Sin embargo, resulta interesante constatar que es específicamente entre los años cincuenta y setenta que aparecieron numerosas ediciones de las obras de Bórojov en lengua castellana.

En 1951 la Editorial "Pueblo Judío" editó "Nuestra Plataforma. Bases del sionismo proletario", traducido por Arié Ben Ami (1923-1997), bajo la supervisión de la Hanagá Helioná (Dirección General) del Hashomer Hatza'ir. ${ }^{16}$ El traductor Arié Slotzky solía firmar artículos y demás publicaciones con el sobrenombre de Arié Ben Ami. Había nacido en Vilna y a los 4 años había emigrado a Buenos Aires con su familia. En Argentina militó en el movimiento Hashomer Hatza'ir y finalmente emigró a Palestina en 1946. Combatió en la guerra de independencia de Israel en el frente sur y posteriormente participó en la fundación de Ga'ash, el primer kibutz latinoamericano del Hashomer Hatza'ir, donde murió hacia fines del 
siglo XX. Desde sus años de juventud en Argentina, Slotzky desarrolló la pasión por la traducción. Para él era fundamental compartir con sus compañeros de habla hispana el material político que llegaba a sus manos en yidish, inglés y hebreo, pero no menos importante y significativo fue para él el desafío de enfrentarse a una nueva lengua y tratar de perfeccionarse en ella. Su traducción del yidish de la obra de Bórojov "Nuestra plataforma" cuando aún no cumplía sus 30 años, fue la cima de su carrera como traductor. ${ }^{17}$

Dos años después, en 1953, Bar Kojba Malaj tradujo del yidish varios textos que compiló bajo el título "Ber Bórojov, su vida y su obra”, ${ }^{18}$ editado por la Biblioteca Borojovista Dror de Buenos Aires junto con una nota biográfica. Bar Kojba Malaj provenía del movimiento Dror de Argentina y también alcanzó a militar en el Partido Socialista Argentino junto con intelectuales como Andrés López Accotto y Leopoldo Portnoy. Ejerció también el periodismo en Mundo Israelita ${ }^{19}$ y a la edad de 38 años decidió emigrar a Israel, al kibutz Mishmar Haneguev. Tiempo después, se radicaría definitivamente en Jerusalén, donde empezó su carrera como prolífico traductor ${ }^{20}$ Además de la obra de Bórojov, tradujo numerosas obras literarias hebreas, ${ }^{21}$ así como investigaciones de corte académico. ${ }^{22}$ Murió en Jerusalén en 1995.

Todas las ediciones de las obras de Bórojov en español -aparecidas entre 1968 y 1979- están basadas en las mismas traducciones originales de Arié Slotzky (Ben Ami) y Bar Kojba Malaj, de principios de los años cincuenta. En el año 1979, José Luis Najenson coordinó la primera edición crítica, de corte académico, en un volumen titulado "Nacionalismo y lucha de clases", que recoge los textos fundamentales de Bórojov traducidos en los años cincuenta, junto con algunos artículos que recién vieron la luz en lengua española, a partir de la traducción del inglés que llevó a cabo Stela Mastrángelo. ${ }^{23}$

Al igual que otros teóricos marxistas fundamentales, Bórojov fue conocido no sólo a partir de que fuera traducido sino, además, de que fuera interpretado. En otras palabras, las traducciones de Bórojov al español aparecían acompañadas de comentarios de ideólogos sionistas-marxistas que actualizaban, complementaban y llenaban lagunas que dejaba el texto original. El objetivo, en la mayoría de los casos, 
era utilizar la teoría borojoviana como herramienta de análisis de la realidad de las comunidades judías de Occidente en la segunda mitad del siglo XX. Estos comentarios alcanzaron, en un momento dado, una preponderancia similar a la del texto original y se convirtieron en teoría borojovista. En este contexto, vale la pena remarcar que, salvo el caso de José Luis Najenson, ${ }^{24}$ casi todos los intérpretes de Bórojov cuyos textos acompañaban las diversas ediciones de este pensador marxista- son oriundos de Europa del Este, que inmigraron a Palestina o América. Entre ellos se encuentran Daniel Ben Najúm, ${ }^{25}$ Raphael Mahler, ${ }^{26}$ Meir la'ari ${ }^{27}$ y Jaime Finkielsztejn. ${ }^{28}$ Es así que los textos originales de Bórojov no sólo fueron traducidos al español sino que también lo fueron sus interpretaciones.

\section{Bórojov y la renovación de la identidad judía latinoamericana}

Ciertamente, la motivación que hay detrás de las traducciones de Bórojov al español puede comprenderse a partir del estudio de dos procesos paralelos que ocurren en el pueblo judío en diferentes continentes. Es necesario para ello poner atención al desarrollo de las disputas en el interior del campo sionista socialista en Palestina y en el Estado de Israel a partir de 1948. Estos debates rebasarían las fronteras del naciente Estado judío y contagiarían a parte de los militantes sionistas en las diásporas judías del mundo. La otra cuestión, que sin duda acusa una enorme relevancia a fin de comprender el impacto del borojovismo ahí donde lo hubo, guarda una estrecha relación con procesos históricos y culturales en América Latina, que incidieron sobre sectores específicos del judaísmo latinoamericano.

Los conflictos en el seno del socialismo israelí a principios de los años cincuenta ponen de relieve la discusión en torno a la teoría borojovista. El origen de esta crisis se encuentra en los juicios de Praga y las purgas contra los líderes judíos del Partido Comunista en Checoslovaquia (1952). Uno de los implicados en dichas purgas fue Mordejai Oren, emisario del Partido Mapam en Praga, quien fue acusado de participar activamente en la "conspiración sionista". ${ }^{29}$ Es a partir de este acontecimiento que comienza el desencantamiento y el distanciamiento del Partido Obrero Unificado de Israel (Mapam) con respecto de la Unión Soviética. Sin embargo, no todos los miembros del partido apreciaron lo sucedido de la misma forma. El desacuerdo en torno a este álgido asunto generó la escisión del grupo alineado 
incondicionalmente con la Unión Soviética, denominado Si'at Smol (facción de izquierda). Esta facción, constituida por Abraham Berna y Moshé Sneh, terminó por integrarse al Partido Comunista israelí (Maki).

Con el propósito de diferenciarse de sus rivales de Si'at Smol, el liderazgo de Mapam y su movimiento juvenil, el Hashomer Hatza'ir, se adhirió con mayor intensidad que antes al borojovismo. A partir de esta disputa política, Bórojov se transformaría por primera vez en brújula ideológica y piedra angular de la ideología del Mapam, del Hashomer Hatza'ir y su movimiento kibutziano, el Kibutz Ha'artzi. Así es como Meir la'ari, líder indiscutible del Partido Mapam, sostiene a partir de este periodo que Bórojov complementó la teoría estalinista de la cuestión nacional, permitiendo así entender, dentro de este contexto, la particularidad del pueblo judío. Según la’ari, toda premisa marxista que rechazase a Bórojov, no podría ser a la vez sionista. Sus rivales de Si'at Smol, la facción de izquierda, percibían en cambio, que Stalin había contribuido de manera suficientemente eficaz para explicar la cuestión nacional, y su teoría se sostenía por sí sola. ${ }^{30}$ Para la'ari el marxismo que niega a Bórojov está condenado a caer en el cosmopolitismo, palabra peyorativa en el léxico marxista de aquel entonces. Bajo el impulso de este debate salieron hacia América Latina emisarios de Israel que, entre muchas otras tareas, difundieron el borojovismo en las diferentes diásporas donde funcionaban los movimientos Dror y Hashomer Hatza'ir.

Y las ideas de Bórojov cayeron en tierra fértil. Para entender la acogida de este pensador marxista entre sectores particulares del judaísmo latinoamericano es preciso prestar atención al acontecer intelectual, social y político en los países donde estaban insertas dichas comunidades. Ciertamente, para cuando las obras de Bórojov son traducidas al español, el debate entre los sionistas socialistas y el Bund se ha desvanecido, se ha convertido en un asunto histórico reciente, pero sin importancia significativa en el debate político de cara al futuro del pueblo judío. Sin embargo, la obra de Bórojov se traduce y da a conocer al público latinoamericano, y podríamos decir más precisamente al público judío, con objetivos deliberadamente políticos. ¿En qué consistían? 
Si duda, los judíos en el continente americano se iban integrando a los países que les acogían, sin restricciones significativas en comparación con las que habían experimentado en sus países de origen. ${ }^{31}$ Las barreras del lenguaje cayeron definitivamente a partir de la segunda generación, y los inmigrantes y sus familias comenzaron a progresar económicamente. Puesto en otras palabras, desapareció el proletariado judío como tal. ${ }^{32}$ Ello no significa que no existieran más trabajadores judíos asalariados, pero no dentro de un colectivo que se asumiera como tal. Dicho lo anterior, emerge la pregunta acerca de la necesidad del sionismo obrero en general, y de traducir las obras de Bórojov como brújula política para una nueva generación de judíos, que desarrollan sus vidas en condiciones y territorios distantes a las que les dieron origen. ${ }^{33}$

Parte de la respuesta a este interrogante reside en las características que reviste el debate intelectual en Latinoamérica. Durante el periodo que aquí tratamos, adviene en América Latina una nueva generación de intelectuales cuyo signo identitario es la preocupación ante las problemáticas políticas. Predomina una cultura libresca y se percibe una sensación de cambio, de optimismo y rebeldía. Se abren perspectivas de un cambio social y se desechan antiguos referentes. ${ }^{34}$ El marxismo empieza a ejercer una atracción sustancial como doctrina explicativa de los conflictos sociales en Latinoamérica para capas intelectuales que rebasaban las tradicionales y reducidas esferas de los partidos comunistas. El marxismo se perfila así, como “(...) la herramienta conceptual más avanzada de la época para el estudio de la realidad social y sus conflictos". (Ponza, 2008, pp. 77-78) La generación de la que hablamos se forja al calor de los debates en torno a Cuba y su revolución. ${ }^{35}$ Es la época de las grandes movilizaciones estudiantiles. Es en este período, también, que son descubiertas, entre el público intelectual y universitario hispanoparlante, las obras de pensadores e ideólogos marxistas que habían sido apartados por el estalinismo, como es el caso de Lukács, Gramsci, Luxemburgo, Bujarin, Kautsky, etcétera. ${ }^{36} \mathrm{El}$ descubrimiento e interés por las obras de Ber Bórojov puede ser sin duda apreciado como parte de un más amplio despertar de la conciencia marxista en América Latina, desligada ahora de la tradicional línea estalinista que había predominado por un largo período en los círculos de la izquierda en el continente. 
Bórojov fue un teórico marxista y sus postulados fueron reprimidos durante décadas de estalinismo. Ahora, junto con muchos otros, aparecía de nuevo en escena.

Aunado a lo anterior, Bórojov fue necesario a fin de encontrar una respuesta en clave marxista a los argumentos de grupos e intelectuales que manifestaban abiertamente posiciones antisionistas desde la izquierda. En el período en que Bórojov se difunde, ya opera la ofensiva marxista antisionista entre ciertos grupos de la intelectualidad marxista en América Latina, judía y no judía. Además del texto clásico

de Carlos Marx, "La cuestión judía", ${ }^{37}$ la traducción y edición de la obra de Abraham León, "Concepción marxista de la cuestión judía", iba alcanzando una popularidad considerable ${ }^{38}$ y la introducción que Carlos Etkin hiciera de esta obra, anuncia ya la audiencia a la que el texto se dirige: "Son su vida y sus ideas [las de Abraham León] las que evocamos y exponemos en la síntesis de este trabajo, que realizamos con la mirada puesta en la nueva generación judía argentina y latinoamericana" (León, 1965, p. 7).

Etkin relata los avatares biográficos de Abraham León como militante del movimiento Hashomer Hatza'ir en Bélgica, que terminó por desengañarse del sionismo, que lo atraía "como una embriaguez religiosa" para adherirse a las filas del internacionalismo revolucionario (León, 1965, pp. 17, 21-22). Ello obligó a León a replantear los orígenes de la cuestión judía y las vías para su solución, que progresivamente se fueron distanciando de las de Ber Bórojov.

Según Bórojov, el proletariado judío no puede luchar eficazmente por el socialismo en virtud de la estructura anormal de la nación judía, falta de territorio y economía propios, debe actuar en los sectores periféricos de la producción (los medios de consumo), estándole vedado el acceso a los sectores básicos de la economía (minas, metalurgia, ferrocarriles, agricultura, etc.). La introducción de la maquinaria y de la gran industria desplaza continuamente al semiartesano judío. El problema nacional le impide resolver su problema social. Por eso, para poder luchar por el socialismo es indispensable, según Bórojov, que la nación judía se normalice. Esto sólo puede hacerlo si cuenta con un territorio propio. Por razones 
materiales que no nos detendremos a exponer, Bórojov "demuestra" que ese territorio puede ser únicamente Palestina, llegando así con su argumentación "materialista" a idéntica conclusión que el idealismo religioso del sionismo burgués. (León, 1965, p. 18)

La proximidad cronológica que hay entre las primeras traducciones de Bórojov y la primera traducción de la obra de León, nos da indicios de que el debate se había abierto. La utilización de las comillas que hace Etkin pone de manifiesto la disputa que se hace efectiva entre el campo sionista que reivindica a Bórojov, y el asimilacionista que se erige sobre la concepción materialista de León. Etkin considera esencial para la juventud judía latinoamericana entender la concepción materialista de Abraham León, a fin de resistir lo que considera la “(...) intensa presión ideológica y organizativa del sionismo, dirigida a impedir su integración [la del judío] en el proceso de la revolución nacional, que es la vía natural de solución a la cuestión judía en nuestro continente" (León, 1965, p. 24).

Así, tal como lo ha señalado Ben Najum, Bórojov refutaba lo que a su entender eran las "concepciones erróneas" que imperaban en los círculos del socialismo judío, y en especial en sus percepciones del problema nacional. Sus rivales eran, por un lado, el cosmopolitismo, que niega de raíz la importancia del problema nacional, y por el otro, el culturalismo, que encuentra la solución en la autonomía cultural exclusivamente, sin necesidad de independencia territorial (el Bund) (Bórojov, laari, Ben Najum 1968, p. 49). Como ya hemos mencionado, en las décadas que nos ocupan en este trabajo el debate con el Bund se va debilitando. Fuera de su contexto europeo-oriental, el movimiento bundista va perdiendo su base de apoyo. En cambio, soplan en América Latina vientos favorables a la integración, a la asimilación y no al aislamiento. Por tanto, será de mayor relevancia este debate contra el cosmopolitismo y la participación de los judíos en la izquierda local al momento de evocar los principios borojovistas.

También las traducciones de Bórojov anuncian estar dirigidas a un público básicamente juvenil. El prefacio del libro traducido por Bar Kojba Malaj en 1953 se titula "A los jóvenes": 
Creemos que, por primera vez en el país, se publica una antología de las obras de Ber Bórojov en lengua castellana. No tenemos noticias, tampoco, de que alguna vez ello se hubiera hecho en cualquier otro lugar. Esta experiencia, por tanto, adquiere singular importancia, máxime si se tiene en cuenta que la gran mayoría de la juventud israelita de la Argentina -y de Sudamérica- utiliza básicamente el idioma español.

Es a la juventud a quien con preferencia dedicamos esta selección. El sionismo, durante mucho tiempo, fue considerado una ideología utópica, "reaccionaria" y poco menos que prohibida. En esa época amarga, los pensadores hebreos tuvieron que enfrentar ataques despiadados y hacer esfuerzos denodados para esclarecer a las masas y orientarlas hacia el camino de la redención nacional. $Y$ entre esos luchadores ocupa un lugar descollante Ber Bórojov. (Bórojov, 1953, p. 7)

Bórojov pasó así a ser sobre todo un asunto de jóvenes. En este sentido, el psicoanalista José Itzigson ha demostrado que la crisis generacional y el rechazo a las formas judías tradicionales entre la generación de jóvenes judíos argentinos y uruguayos de los años cincuenta y sesenta, produjo una identificación masiva con el sionismo e Israel. Se trataba de una nueva síntesis entre la necesidad de seguir siendo judío y la necesidad de diferenciarse de los modelos y consignas familiares contradictorios, debido a que los valores que la familia transmitía como vehículo esencial de socialización ya no correspondían con las exigencias de un medio que había cambiado. Para muchos de los jóvenes que visualizaron el mensaje familiar como contradictorio $-\mathrm{y}$ entre ellos los que afluyeron al campo del sionismo socialista- existió también una identificación fundamental e intensa con los movimientos de la izquierda marxista local. De esta manera -señala Itzigson- el prestigio de la revolución cubana sedujo a muchos estudiantes judíos en América Latina, que ansiaban militar en las filas de la izquierda revolucionaria pan-latinoamericana. Tal fenómeno agudizó el problema de identidad de los jóvenes judíos, en tanto que este tipo de movimientos eran reacios a reconocer la especificidad grupal judía o la existencia de problemas específicos judíos que exigiesen una solución particular, distinta de la solución general de tipo populista o revolucionario. El problema se hacía incluso más severo cuando estos movimientos se mostraban abiertamente en contra del sionismo, en contra de las fuerzas progresistas de Israel ${ }^{39} \mathrm{y}$, en ocasiones, en contra de la existencia misma del Estado judío. ${ }^{40}$

El marxismo como corriente ideológica general, no pudo mantenerse por completo al margen del antisemitismo. Podemos decir, que este letal virus infectó también a amplios sectores comunistas y representantes del socialismo radical. En ciertos aspectos importantes, la Nueva Izquierda, al igual que el 
campo comunista ortodoxo, siguió haciéndose eco de una simplificación vulgar y grosera de los argumentos invocados contra el sionismo y el pueblo judío antes de 1914. Así, amplios sectores marxistas sostuvieron tradicionalmente, que la supervivencia de la colectividad judía -sea ella meramente religiosa, nacional o estatal- era políticamente reaccionaria. ${ }^{41}$ Con ello, quedaba cerrada para muchos jóvenes judíos la vía de identificación hacia una posición política progresista o de izquierda, a menos que abjuraran de su identidad judía. ${ }^{42}$ Pero los sionistas socialistas descubren en Bórojov la posibilidad de participar en el diálogo marxista. En su primera edición, la revista Enfoque, suplemento teórico del periódico Nueva Sión de Argentina, concluía que:

La concentración territorial y el nacimiento de una clase obrera judía va agudizando la lucha de clases en Israel, proceso que es simultáneo al de la concentración de las diásporas. Y si bien el socialismo no será realidad inmediata en Israel -puesto que el 85 por ciento del pueblo todavía se halla fuera de sus límitesno cabe duda de que las masas judías gozarán del socialismo sólo en Israel, y que, asimismo, sólo el socialismo en un período en que la concentración de las diásporas esté más avanzado, será el que habrá de asegurar la coronación del proceso de la concentración territorial del pueblo. (Enfoque, 1962, p. 8.)

$\mathrm{Y}$ frente a las tendencias asimilacionistas afirma:

La historia de nuestros tiempos avanza a pasos agigantados. La asimilación cultural judía en la diáspora es un hecho, pero también es un hecho que la integración total de los judíos en sus diásporas es imposible. Los cataclismos históricos no dejan tiempo para que esa asimilación se transforme en integración. Es también realidad que el pueblo judío está alcanzando cumbres desconocidas de actividad creadora a través de su normalización en Israel, donde ha surgido, entre otras muchas, la máxima creación del genio judío, la forma social denominada kibutz, instrumento fiel de la lucha clasista a la vez que célula ejemplar de la sociedad del futuro. (Enfoque, 1962, p. 8.)

Ciertamente, en el período que aquí estudiamos, las reivindicaciones de liberación nacional en América Latina se van ajustando cada vez más a las de justicia social. Jóvenes sionistas se sirven de las tesis borojovistas con el fin de legitimar el sionismo como movimiento de liberación nacional, equiparándolo con los movimientos por la autodeterminación de los pueblos propios del continente latinoamericano. “¿Cómo leer a Bórojov en la situación latinoamericana de hoy?”, se cuestiona Leonardo Senkman en su prólogo a la edición de las obras de Bórojov:

Primeramente: enmarcando su fundamentación marxista de la cuestión nacional en nombre de un proyecto revolucionario socialista por el que siempre luchó. Así cobra todo el sentido liberador el otro proyecto que iluminó al otro con su específico resplandor: arrancar la opresión de las naciones explotadas. 
En segundo lugar: su lectura en estas latitudes, hay que insertarla en la asonada revolucionaria del Tercer Mundo, en su combate antiimperialista y por la construcción del socialismo. La experiencia vivida por Bórojov en la "Cárcel de las naciones" austro-húngaras y en el imperio multinacional zarista a principios de siglo ganan, 60 años después, una dimensión descolonizadora insólitamente contemporánea. Esta doble lectura vale para la revolución latinoamericana como para la sionista. (Bórojov, 1973, p. 7)

Es en este contexto que la lectura e interpretación de Bórojov adquiere un papel fundamental. Ello es apreciado también por los rivales del borojovismo en América Latina e Israel. En el año 1971 también aparecian en círculos de la extrema izquierda israelí acusaciones hacia la directiva de los movimientos sionistas socialistas de estar reviviendo artificialmente a Bórojov con el fin de desviar a los jóvenes judíos del mundo occidental y América Latina de los procesos significativos que acontecían en sus propios países. Uno de los militantes del grupo Matzpén, ${ }^{43}$ Moshé Machover escribe -tal vez bajo la inspiración de la obra de León- que la difusión de las ideas de Bórojov no es otra cosa sino un acto de propaganda deliberado de los emisarios de la "maquinaria sionista" que maquiavélicamente promovían una ideología en la que no creían, a saber, el borojovismo. Todo ello se llevaba a cabo -según Machover- con el fin de alejar a los jóvenes judíos de los procesos revolucionarios de América Latina, del castrismo y del trotskismo (Machover, 1971, p. 31). Es evidente que tal suposición, de calidad un tanto paternalista, conseguía subestimar la capacidad intelectual y las necesidades de construir una identidad judía alternativa de esta juventud judía, dibujándola sólo como una víctima pasiva de la "propaganda sionista". Esta afirmación, sin embargo, pone en evidencia el eco que los argumentos de carácter trotskista tuvieron entre sectores de la izquierda radical israelí. Ciertamente, muchos jóvenes judíos de izquierda en América Latina no podían, ni querían, escapar del discurso marxista propio del período. Se sentían profundamente comprometidos con la ideología del marxismo revolucionario, pero le adscribían una gran relevancia a la generación de una identidad judía desligada del modelo familiar. El borojovismo otorgó a esta juventud judía la posibilidad de dignificar su judaísmo en un contexto de efervescencia social. Dicho de otra manera, el borojovismo proporcionaba las claves y los argumentos necesarios para reivindicar el sionismo en una coyuntura predominantemente marxista, otorgándole legitimidad al proyecto del Estado judío en general, así como a la suma de proyectos personales que procuraban resolver una crisis 
identitaria a través de la emigración a Israel. En este sentido, la particularidad de Bórojov, a diferencia de otros pensadores sionistas, estriba en el hecho de que partía de premisas marxistas, de las cuales se deducía el sionismo. Sus tesis podían esgrimirse como un argumento frente a la ofensiva comunista de sectores del judaísmo latinoamericano, como sucedía en el caso argentino, ${ }^{44}$ pero también contribuía a acercar al sionismo a sectores de la izquierda latinoamericana que eran potenciales aliados del sionismo progresista.

A partir de los años sesenta, cantidades proporcionalmente significativas de jóvenes judíos se habían vinculado con los movimientos estudiantiles en distintos países latinoamericanos, en donde predominaban holgadamente las fuerzas políticas de izquierda (Nahum 1999, pp. 307-309). Justamente en octubre de 1968, tras la matanza de Tlatelolco, aparece el primer ejemplar del órgano difusor de la juventud del Hashomer Hatza'ir en México, llamado Contra la corriente. La editorial de este periódico se refiere en términos casi apocalípticos a los sucesos que convulsionan el mundo contemporáneo, y a continuación hace un llamado a la juventud judía del país a integrarse a las filas del sionismo socialista:

A la juventud judía:

Existe un sentimiento vehemente de inconformidad y malestar ante la sociedad en que vivimos. En el momento actual se está librando en casi todos los puntos del planeta, la lucha definitiva entre los oprimidos y sus opresores; entre la humanidad alienada y los sistemas de poder que tienden a perpetuarla. [...]

O bien los judíos de la Diáspora coadyuvan al advenimiento revolucionario en que viven y, siguiendo en esto a la lógica histórica, corren el riesgo de desaparecer como minoría históricamente superada; o bien se integran sin reservas al sionismo socialista para preservar y consolidar los valores creados por la vanguardia jalutziana que expresan las realizaciones más auténticas del humanismo socialista, y además, para consumar al mismo tiempo el movimiento Judío de Liberación Nacional del cual nació el Estado de Israel. (Contra la corriente, 1968)

Inclusive en colectividades judías como la de Chile, país donde existía una amplia tradición democrática hasta antes de 1973, y donde la izquierda no se caracterizaba por ser virulentamente antisemita o antiisraelí, las tesis borojovistas se convirtieron en una herramienta para la colocación del sionismo en el ámbito de la legitimidad marxista, como movimiento de liberación nacional. Así surgió el Frente de Izquierda Sionista (FIS), ${ }^{45}$ que en uno de sus manifiestos declaraba que: 
[es Bórojov] quien más certeramente enfoca el núcleo mismo del problema [judío]: Los judíos se alejan paulatinamente de la naturaleza, de los sectores primarios de la economía, deslizándose hacia los secundarios (intermediación del comercio y las finanzas), y dirigiéndose finalmente hacia las ramas terciarias, hacia las profesiones liberales. La resultante de este proyecto es lo que Bórojov llama "la pirámide invertida"; es decir, una ausencia total de campesinado, una capa delgadísima de proletariado, sobre todo en la manufactura, un artesanado precario, que sufre las consecuencias de todos los artesanados después de la revolución industrial, y finalmente, las clases medias, también nucleadas en ramas especializadas y abocadas en el fin de su evolución, a ciertas profesiones liberales. Ver en un pueblo así, compuesto de clase media e intelectuales, a los artesanos de una revolución social, es un absurdo. Si bien es cierto que -dado su situación vulnerable y precaria- muchos de sus miembros se alinean generalmente a las filas del progreso, y que ciertos sectores, sobre todo provenientes de la clase media pauperizada, se transforman en radicales y revolucionarios, lo que choca aquí es la estructura económica anormal, la imposibilidad patente de participar en la lucha de clases definitiva.

[...] los judíos están a merced de los acontecimientos. En ninguna parte son ellos el sujeto de la historia, ya sea como grupo, ya como individuos, haciendo abstracción de aquellos que logren labrarse un camino individual. Su estructura económica les impide cumplir una función política independiente. Sufren los altibajos de la historia, y en numerosos casos, son sospechosos de deslealtad en el momento en que intentan asumir su destino. ${ }^{46}$

EI FIS había entablado relaciones muy cercanas con Salvador Allende. Junto con otros grupos de la izquierda sionista, había organizado el comité chileno pro paz en el Medio Oriente, que, usando la consigna de que "sólo la paz es revolucionaria en el Medio Oriente", había acercado a notorias figuras de la izquierda chilena al sionismo socialista. En el directorio del comité pro paz figuraban el escritor Manuel Rojas, uno de los fundadores de la Central Única de Trabajadores, el senador Rafael Gumucio, líder del Movimiento de Acción Popular Unitaria, Clotario Blest, Hugo Cancino, dirigente del movimiento Iglesia Joven, el líder socialista Erich Schnake y algunas personalidades judías chilenas de filiación izquierdista. Los jóvenes de izquierda judíos, fieles a su adhesión a la causa de la Unidad Popular, declaraban tras la victoria de Allende: "hacemos votos para que en medio de los ingentes esfuerzos que tendrán que invertirse en Chile para imponer un justo régimen socialista, se halle un respiro necesario para apoyar las actuales gestiones de paz en el Medio Oriente", combinando así las visiones de la izquierda chilena con las de la izquierda sionista (Sznajder 1993, pp. 139-140). EI FIS no solamente había adoptado las premisas del borojovismo sino que, además, había logrado que una parte de la izquierda chilena las aceptara. ${ }^{47}$ No se puede decir, sin embargo, que en muchos países de América Latina las juventudes sionistas de izquierda hayan conseguido los mismos logros del FIS en Chile, al hacer partícipe a la izquierda local de los supuestos borojovistas. 
Como corolario, resulta por demás interesante constatar el hecho de que la lectura de Bórojov condujo a muchos de los jóvenes que lo estudiaron a tomar la decisión de vivir en un kibutz. Esta conclusión difícilmente se deriva de los escritos de Bórojov, mayormente dirigidos a la causa del proletariado urbano. La idea del kibutz, en cambio, se sustentaba sobre elementos que eran más propios del anarquismo rural o de ciertas vertientes del socialismo utópico, consolidándose finalmente como una experiencia judía de socialismo voluntario. Pero el borojovismo constituyó la herramienta que logró articular en el lenguaje marxista, necesario en el contexto del discurso intelectual de aquella época, la emigración a Israel y el kibutz como alternativa revolucionaria. ${ }^{48}$ Ello es evidente en el caso latinoamericano y es altamente probable que lo haya sido entre juventudes judías de Norteamérica y Europa Occidental. Ése, sin embargo, es un tema que requiere de un estudio adicional.

\section{Conclusión}

La historia del marxismo es la historia de una gran variedad de corrientes y vertientes interpretativas. En efecto, la existencia de un canon textual produjo los más variados comentarios en diferentes puntos del planeta donde esta literatura tuvo difusión. La historia del marxismo es, en otras palabras, la historia de los marxismos. Como una de sus corrientes, el borojovismo se destaca por su auge particular entre sectores importantes de la juventud judía latinoamericana entre los años 1950 y 1980 . Fueron estos los años de efervescencia de movimientos revolucionarios e intelectuales que confirieron al marxismo una posición privilegiada en la explicación de los fenómenos sociales y en el replanteamiento de la cuestión nacional en América Latina. Ciertamente, el borojovismo pasó inadvertido entre amplios círculos de marxistas, pero cumplió un papel fundamental en la recreación de una identidad judía bajo el amparo de una visión progresista de la historia. El borojovismo permitió a más de una generación de jóvenes judíos reenmarcar el sionismo como movimiento de liberación nacional del pueblo judío, en un contexto más amplio de lucha y reivindicación de los pueblos por su propia autodeterminación, en armonía con los supuestos de la izquierda latinoamericana y marxista. En este sentido, el interés por el borojovismo rebasó fronteras y se desarrolló como un fenómeno panamericano. Sería un poco exagerado atribuirle al borojovismo la emigración de miles de jóvenes de tendencia izquierdista de América Latina a Israel. Sin 
embargo, sí podemos afirmar que Bórojov fue el fundamento teórico más importante para dar legitimidad a dicho proyecto de vida entre las capas intelectuales de esta juventud.

De forma adicional, podemos decir que Bórojov produjo herramientas teóricas de gran utilidad para el estudio y la comprensión adecuada de la cuestión nacional. Lamentablemente fue un marxista ignorado por amplios sectores de académicos que no pertenecían al pequeño núcleo de marxistas judíos y podría sugerirse que este artículo puede haber cumplido ya su cometido, si es que, de alguna manera, ha contribuido a remover esa montaña de olvido que -en palabras de José Luis Najenson- yace sobre los escritos y el pensamiento de Bórojov, y en específico en lo que toca a los estudiosos y analistas de la cuestión nacional y el marxismo en América Latina. 


\section{Notas}

${ }^{1}$ Esta investigación se llevó a cabo con el apoyo de la Beca Golda Meir y del Departamento de Estudios Románicos y Latinoamericanos de la Universidad Hebrea de Jerusalén. Agradezco la cooperación del Dr. José Luis Najenson, de Eitan Melnick y Yehoshua Faigón (bendita sea su memoria) en la elaboración del presente artículo. Agradezco también la valiosa ayuda de Avi Aronsky, de Lutz Fiedler y Kevin Ari Levin en la localización de textos y fuentes necesarios para fundamentar esta investigación.

${ }^{2}$ Najman Syrkin (1868-1924), judío de origen ruso, fue uno de los fundadores y teóricos del sionismo laborista. A diferencia de Bórojov, Syrkin no se consideraba marxista. Sobre Syrkin puede consultarse la obra de Jonathan Frankel, Prophecy and Politics: Socialism, Nationalism and the Russian Jews 18621917, 1981, pp. 288-328.

${ }^{3}$ Moisés Hess (1812-1875) fue un cercano colaborador de Marx que, hacia los últimos años de su vida, retornó al judaísmo. Es reconocido como uno de los fundadores del sionismo socialista. Véase: Avineri 1985.

${ }^{4}$ Aharon David Gordon (1856-1922) es considerado el ideólogo que orientó espiritualmente el sionismo laborista con su percepción quasi religiosa del trabajo agrícola. Véase: Schweid 1981, pp. 11-22; y Shapira 1987, pp. 130-141.

${ }^{5}$ Najenson 1981, pp. 727-755. Carlos Monsiváis parece haber mostrado un interés singular en Bórojov, con el fin de comprender de manera más precisa el problema étnico-nacional en México. Comunicación personal con Enrique Semo, noviembre de 2011.

${ }^{6}$ Véase: Aronson, 1966, pp. 144-171.

${ }^{7}$ El más reconocido biógrafo de Ber Bórojov hasta la fecha es Matityahu Mintz, cuyas obras han sido publicadas básicamente en hebreo. Véase por ejemplo: Ber Borokhov. Circle One (1900-1906), 1976 (en hebreo); Id. New Times - New Tunes, 1988 (en hebreo). Otro brillante estudio sobre Bórojov puede consultarse en: Frankel 1981. En el capítulo 7 de este libro (pp. 329-363), Frankel consigue separar al hombre mítico del hombre teórico, y presenter lúcida y acertadamente una imagen de Bórojov y su entorno político y social. 
${ }^{8}$ Movimiento precursor del sionismo político cuyo objetivo principal era la colonización de Palestina. A raíz de los pogromos de 1881 en Rusia, el movimiento atrajo especialmente el interés de la intelectualidad judía.

${ }^{9}$ Partido obrero sionista socialista, fundado en 1903 y constituido en organización mundial desde 1907. A partir de 1916, Po’alei Tzión fue admitido en el seno de la Internacional Socialista.

${ }^{10}$ Dov Ber Bórojov, Nacionalismo y Lucha de Clases, José Luis Najenson (ed. y comp.), 1979, pp. 7-8. Salvo en los casos expresamente señalados, todas las citas de Bórojov provienen de la edición crítica de Najenson.

${ }^{11}$ Bund en yidish significa "unión". Este partido socialista judío fue fundado en Vilna, Lituania, en 1897. Su nombre completo era Unión General de Trabajadores de Lituania, Polonia y Rusia. Acerca del Bund, consúltese: Frankel 1981, pp. 171-257.

${ }^{12}$ El neologismo estígico fue empleado por Bórojov para significar algo desorganizado, que no está dirigido ni encaminado. La palabra stigia en ruso y en yidish, y el vocablo stigi en hebreo provienen de la voz griega stoigeión, que significa base, principio, material primario. Stihijno: spontaneous, uncontrolled. Wheeler y Unbegaun 2007, p. 486. El diccionario hebreo de Abraham Even Shoshán define así la palabra stigi: "lo que se realiza sin la intervención del hombre o de su voluntad, sino por imperio de la naturaleza y de sus poderes: un diluvio, una inundación, la erupción de un volcán, son fenómenos estígicos". (Even Shoshán, 1993, p. 486, en hebreo).

${ }^{13}$ Citado en Finkielsztejn 1968, p. 16.

14 Mordejai Anilewitz (1919-1943), fue miembro del movimiento Hashomer Hatza'ir en Polonia y comandante del levantamiento en el gueto de Varsovia.

${ }^{15}$ Sobre la formación intelectual de las juventudes sionistas en Argentina y su papel en la vida de la colectividad judía, consúltese la tesis de maestría de leraj Grinfield "Hajativot hatze'irot hatzioniotsotzialistiot bearguentina shel shnot hashishim bamea esrim. Havnayat hashkafot 'olam [Las juventudes sionistas socialistas en Argentina durante los años sesenta del siglo XX: la construcción de una concepción de mundo]", tesis de maestría, Universidad Hebrea de Jerusalén, 2006 (en hebreo). 
16 "Nuestra Plataforma”, de Ber Bórojov fue el texto que inauguró, en la Editorial Pueblo Judío, una serie de publicaciones concernientes a los orígenes y los problemas del sionismo socialista. Fue editado con una introducción de Daniel Ben Najum. La Editorial Pueblo Judío publicaría posteriormente las obras de autores como Meir la’ari, Peretz Merjav y León Peretz. Véase: Bórojov, 1951.

${ }^{17}$ Comunicación con Yaron Slotzky, Jerusalén, 1 de diciembre de 2009.

${ }^{18}$ Además de un prólogo, anotaciones biográficas y una cronología, este volumen incluye los siguientes textos: "Trascendencia e inmanencia del sionismo", "El factor personal en la militancia sionista", "El odio antijudío", "Galut normal y Galut anómalo", "Pueblo, cultura, hogar: la tríada de Sión", "Sión y territorialismo", "Fundamentos materialistas del sionismo", "La cuestión judía: un problema de interés mundial", "La concentración antisionista", "El desarrollo económico del pueblo judío", "Los intereses de clase y la cuestión nacional", "Anomalía de la extraterritorialidad", "La clase trabajadora judía", "Teoría de la base estratégica", "En defensa de los derechos judíos” (Bórojov, 1953).

${ }^{19}$ Periódico fundado por judíos argentinos simpatizantes del sionismo en 1923.

${ }^{20}$ Senkman, 1995, pp. 103-105.

${ }^{21}$ Durante treinta años, Bar Kojba Malaj estuvo a cargo de la edición en español de la revista Ariel, emitida por la División de Relaciones Científicas y Culturales del Ministerio del Exterior de Israel. Tradujo, entre otras, las obras de autores como Amnón Shamosh, Amos Oz y Shmuel Yosef Agnón.

${ }^{22}$ Entre otras investigaciones, Bar Kojba Malaj tradujo la obra de Raanan Rein sobre la alianza FrancoPerón, así como la obra de Shlomo Ben Ami sobre la guerra civil española.

${ }^{23}$ Además de una introducción de José Luis Najenson, este volumen recoge los siguientes textos: "Los intereses de clase y la cuestión nacional" (retomado de la traducción de Bar Kojba Malaj, 1953), "Nuestra plataforma" (retomado de la traducción de Arié Ben Ami,1951), "La concentración antisionista" (retomado de la traducción de Bar Kojba Malaj, 1953), "Dificultades del poaleisionismo (sionismo obrero)", "Antisemitismo judío", "Desvalimiento nacional y autosuficiencia nacional", "El nacionalismo y la guerra mundial”, "El jubileo del movimiento obrero judío", "Reminiscencias", "El desarrollo económico del pueblo judío”, “Aarón Lieberman: padre del socialismo judío” (Bórojov 1979). 
24 José Luis Najenson nació en Rosario, Argentina en 1938. Obtuvo su doctorado en Historia por la Universidad de Cambridge en 1981 con la tesis intitulada: Borochovism: an early Marxist theory of the national question. Najenson se autocalifica de antropólogo en primeras nupcias y, al igual que Ben Najum, ha sido un hombre que combinó su reflexión política con la literatura, obteniendo varios premios de narrativa y poesía.

${ }^{25}$ Daniel Ben Najum (1910 Kovna - 1992 Beit Zer'a) fue miembro del kibutz Beit Zer'a del Hashomer Hatza'ir. Poeta, crítico histórico y literario, Ben Najum se dedicó a traducir, explicar y difundir las obras de Bórojov en lengua hebrea. Ben Najum fue el compilador, junto con L. Levite, de los primeros dos volumenes de las obras completas de Ber Bórojov en lengua hebrea. El tercer y último volumen fue editado por L. Levite y Sh. Rehav. Veáse: Borochov, vol. 1, 1955; vol. 2, 1958; vol. 3. 1966. Ben Najúm editó sólo hace algunos años las obras filosóficas de Bórojov en traducción al hebreo. Veáse: Bórojov 1994 (en hebreo). Los apuntes y artículos originales que contiene el archivo personal de Ben Najum pueden consultarse en el archivo lad la'ari de Guivat Javiva en Israel, expediente 16. 55-95. En español, veáse el ensayo "La cuestión nacional en los escritos de Bórojov", en Bórojov, laari, Ben Najum 1968, pp. 49-100; Bórojov 1969, pp. 74-172.

${ }^{26}$ Raphael Mahler fue un historiador materialista del pueblo judío que nació en 1899 en Galitzia, Polonia, y emigró a Estados Unidos en 1937. Fue miembro de Po'alei Tzión Smol (el ala izquierdista del partido Po'alei Tzión que en 1950 se unió con Hashomer Hatza'ir y con Hatnuá Leajdut Ha'avoda, Movimiento por la Unidad Trabajadora, para fundar el Partido Obrero Unificado, Mapam). En 1950 llegó a Israel y un año más tarde fue nombrado profesor de la Universidad de Tel Aviv. (Mahler 1969, pp. 27-38, en hebreo; 1958, pp. 31-42). Los comentarios de Mahler a la teoría de Bórojov fueron traducidos al español en: Bórojov 1979, pp. 46-72.

${ }^{27}$ Meir la'ari (1897-1987). Oriundo de Galitzia, Polonia, fue de los fundadores del movimiento Hashomer Hatza'ir y miembro destacado del Kibutz Merjavia. Es considerado uno de los ideólogos y líderes más importantes del movimiento. La adaptación que la'ari lleva a cabo de la teoría borojovista, fue traducida al español con el título "El borojovismo en nuestros días", en Bórojov, laari, Ben Najum 1968, pp. 7-10. 
${ }^{28}$ Jaime Finkielsztejn fue un importante promotor del borojovismo en Argentina. Nació en 1911 en BrestLitowsk (hoy Bielorrusia) y llegó a Argentina en 1930. Fue un reconocido pedagogo y fundador de la red escolar Scholem Aleijem en Argentina. Fue miembro del presidium del Consejo Mundial para la Educación Judía y presidente del consejo pedagógico del Va’ad Hajinuj Central (Organización de Escuelas Judías) de la comunidad judía de Buenos Aires. Fue, además, un reconocido activista sionista y secretario general de Po'alei Tzión en Argentina, y miembro del secretariado de la Unión Mundial de esta organización (Finkielsztejn 1968). Un año antes vio la luz la versión en yidish del mismo opúsculo bajo el título: Der Gaon fon Paltava. Por los 50 años de la muerte de Bórojov (1967); y "Dos balances - una conclusión. Un enfoque borojovista sobre el presente del pueblo judío", 1961.

${ }^{29}$ Sobre los juicios de Praga y sus connotaciones antisionistas, veáse: Kotic 1998, pp. 194-197 (en hebreo).

${ }^{30}$ La revista titulada Bamishlat, editada por los miembros del kibutz Harel, en las proximidades de Jerusalén, dedica su volumen número 18, del 5 de marzo de 1954, a rememorar un año de la desaparición física de Stalin. Los miembros de Harel se convirtieron en disidentes de la línea oficial de Mapam, alineándose en su gran mayoría con el Partido Comunista. Uno de los artículos del citado volumen está dedicado a la cuestión nacional en el pensamiento de Stalin: "la premisa elemental [de Stalin] es que la cuestión nacional no debe evaluarse por sí misma, sino desde una perspectiva de clase, desde el punto de vista de la revolución proletaria [...] De esta manera la teoría de Stalin no es sino una prolongación de las obras de Lenin, Marx y Engels (en la medida en que éstos trataron la cuestión nacional). Ellos percibieron siempre esta cuestión como subordinada a la cuestión de la revolución, y la única diferencia reside en el hecho de que para Marx y Engels estaba subordinada a la cuestión de la revolución democrático-burguesa y en la época de Stalin pasó a ser parte de la cuestión general de la revolución proletaria, parte de la cuestión relativa a la dictadura del proletariado. De aquí proviene la diferencia entre el combate nacional del proletariado del de la burguesía. En tanto que la burguesía tiende a colocar su exigencia nacional siempre en el centro, vaciándola de todo contenido, a ojos del proletariado, en cambio, la exigencia nacional está subordinada al interés de la lucha de clases. Y no sólo 
a los intereses de clase en su propia tierra, sino que se trata de una cuestión universal y todo problema nacional en cualquier región está subordinada al interés general del proletariado internacional”. Miri 1954, pp. 4-6 (en hebreo).

${ }^{31}$ Véase la evaluación que en 1967 elabora José Jerosolimsky con respecto a las perspectivas de la nueva generación de jóvenes judíos uruguayos, que vive "en una sociedad libre, abierta y en diario contacto con no judíos..." (Jerosolimsky 1967, pp. 80-81).

${ }^{32}$ Veáse la interpretación que hacen de la teoría borojovista autores como Daniel Ben Najúm, Jaime Finkielsztejn y Raphael Mahler.

${ }^{33}$ Marcos Regalsky expresa que el sionismo, "en Argentina y en América en general, carece del impulso directo, económico y migratorio, que tiene en las comunidades populosas de Europa, y eso influye en la estabilidad y el arraigo del movimiento sionista". Citado en Avni 2005, pp. 158-159.

${ }^{34}$ Sobre los intelectuales argentinos y el desarrollo del marxismo en el transcurso de estas dos décadas, véase: Ponza 2008, pp. 74-98.

${ }^{35}$ Para un sector minoritario de la izquierda latinoamericana, sobre todo entre los jóvenes, éste se consideraba el momento de tomar las armas. En los mítines y manifestaciones en el Uruguay, esos núcleos coreaban la consigna "basta ya de dialogar, dadnos armas para luchar". Véase: Turiansky 1997, p. 88.

${ }^{36}$ En Argentina, la publicación de los "Cuadernos de pasado y presente" a partir de 1963, resultó clave para la renovación del pensamiento marxista, generando un fuerte impacto sobre toda América Latina. Ahí fueron editadas las obras de Rosa Luxemburgo, de György Lukács, André Gorz, León Trotsky, Nikólai Bujarin, Antonio Gramsci y el mismo Bórojov.

${ }^{37}$ Se publicaron numerosas ediciones de este texto que Marx redactó en su época de juventud. Veáse, por ejemplo: Marx y Engels 1974, pp. 107-137; y 1967, pp. 16-44. Existe aún en nuestros días un acalorado debate acerca de si este texto, que expresa como corolario "la emancipación social del judío es la emancipación social del judaísmo", es un texto erigido sobre premisas antisemitas o no. Diferentes posiciones con respecto a esta cuestión pueden encontrarse en los articulos de Faurto Pitigliani por un 
lado y de Pierre Vidal-Naquet por el otro (Pitigliani 1975, pp. 3-14; y Vidal-Naquet 2002, pp. 197-211). No pretendemos aquí dar una respuesta definitiva a este interrogante. Aún así, resulta evidente que el texto fue esgrimido por marxistas de tendencia antisemita con el fin de denigrar al judaísmo en el transcurso del siglo XX. Veáse la crítica que elabora Alain Finkielkraut en El judío imaginario, 1982, pp. 87-90.

38 Abraham León nació en Varsovia en 1918 pero creció en Bélgica. Había sido un militante del Hashomer Hatza'ir en su país, pero luego, al comienzo de la Segunda Guerra Mundial, rechazó el sionismo adhiriéndose a continuación al trotskismo. Fue deportado por los nazis a Auschwitz, donde murió en septiembre de 1944. La obra de León fue editada por vez primera en 1953. Abraham León, Concepción marxista de la cuestión judía, ed. tr. Carlos Etkin; una segunda edición apareció en 1965. La obra fue reeditada por Juan Pablos Editor, en 1976. Las citas que aparecen a continuación provienen de la edición de 1965.

${ }^{39}$ Un comunicado firmado por los diferentes partidos obreros de Israel se lamenta de que las fuerzas propaz en Israel no hayan sido invitadas a la conferencia tricontinental de La Habana, en enero de 1966, que tenía por objeto forjar un frente anticolonialista y antiimperialista de los pueblos de Asia, América y África. Este comunicado fue traducido al español y publicado por los periódicos de los movimientos juveniles sionistas de izquierda en América Latina. Véase: Vanguardia. Vocero de la realidad israelí. Publicación del Mapam - Hashomer Hatzair en México 1966, pp.13-15.

${ }^{40}$ Itzigson 1979, pp. 97-98. Sobre la transición generacional y los nuevos dilemas de identidad en la comunidad judía uruguaya durante los años sesenta, véase: Jerosolimsky 1967, pp. 80-83.

${ }^{41}$ Wistrich, 1975, pp. 114-124. Véase la introducción de Etkin al libro de Abraham León, en donde puede leerse: "[El sionismo] divide el frente de lucha antiimperialista, mostrando a los judíos como interesados en su salvación para ellos solos, independientemente de los pueblos que forman parte. Los impulsa contra los movimientos nacionales" (León, 1965, p. 29).

42 Itzigson, 1979, 97-98; y 1976, p. 216.

${ }^{43}$ La organización Matzpén (brújula, en hebreo) fue fundada en 1962 por exmiembros de Maki, el Partido Comunista israelí. Su nombre oficial era la Organización Socialista Israelí y su plataforma era 
anticapitalista y antisionista. La organización estuvo activa hasta los años ochenta. Sobre Matzpén puede consultarse: Greenstein 2009, 85-108; y Schnall 1978, pp. 381-393.

${ }^{44}$ Comunicación personal con Yeoshua Faigón, 18 de febrero de 2009.

${ }^{45}$ En Chile un 4 por ciento del estudiantado general era judío. Los judíos estaban representados en la población universitaria diez veces más de lo que entre la población general del país (Sznajder 1993, p. 138).

${ }^{46}$ Comunicado del Frente de Izquierda Sionista: La izquierda sionista frente al momento actual: Chile, América Latina, Israel, 1972?, p. 1. Tal como lo describe Eitan Melnick, este discurso tuvo resonancia en amplios sectores de la izquierda chilena: "De repente habíamos aprendido un lenguaje que los tipos entendían perfectamente. Utilizabamos sus mismas palabras, sus mismos conceptos [...] hablábamos el mismo idioma, exactamente el mismo idioma. $\mathrm{Y}$ habíamos descubierto nosotros que podíamos construir todo ese edificio que justificaba el agrupamiento de los judíos acá [en Israel], la creación de un Estado, la clase obrera, etc., si sólo nos aceptaban las primeras premisas, podíamos construir el resto del edificio de manera muy fácil... y no había ninguna discusión [...] Bórojov nos permitió entrar a ese club por la puerta principal. Pero lo más fascinante es que vendíamos un producto que todos querían comprar, que lo entendían". Comunicación personal de Eitan Melnik, 5 de febrero de 2009.

47 Comunicación personal de Eitan Melnik, Jerusalén, 5 de febrero de 2009. EI FIS difundió sus postulados a través de diversas publicaciones entre las que se cuentan Orot [Luminarias]. Frente de Izquierda Sionista y Hashomer Hatzair Chile, agosto, 1969; Compromiso, 1972?; así como las memorias de los coloquios por la paz en el Medio Oriente que tuvieron lugar en Santiago de Chile. Veáse: Paz en el Medio Oriente, diciembre, 1968; Paz en el Medio Oriente y en Vietnam, febrero, 1971.

${ }^{48}$ El número de inmigrantes latinoamericanos en Israel en el año 1976 era, según las estimaciones, de 41.000, de los cuales el 20 por ciento, un total de 8.000 inmigrantes, vivían en kibutzim. Los inmigrantes jóvenes que procedían de los movimientos de sionistas de izquierda como Hashomer Hatza'ir, Dror e ljud eran varios miles. Veáse: Ben Israel 1978, pp. 35-41. 


\section{Bibliografía}

ARONSON, Gregor. "Ideological Trends among Russian Jews", EN: FRUMKIN Jacob, ARONSON Gregor, GOLDENWEISER Alexis (Eds.), Russian Jewry (1860-1917), Mirra Ginsburg (tr.), Nueva Jersey, Thomas Yoseloff Publisher, 1966. pp. 144-171.

AVINERI, Shlomo. Moses Hess: Prophet of Communism and Zionism. Nueva York, New York University Press. 1985.

AVNI, Haim, "El sionismo en Argentina: el aspecto ideológico", EN: Judaica Latinoamericana (5): 145168, 2005.

BEN ISRAEL, David. "De América Latina a Israel al Kibutz. 32 años de aliá jalutziana de los miembros de la familia del hashomer hatzair a su federación kibutziana - hakibutz haartzi”. Merjavia, Dfus Merjavia, 1978.

BÓROJOV, Dov Ber. Ktavim Filosofim [Escritos filosóficos], Daniel Ben Najum y Abraham las'ur (Eds., Tr.). Haifa, Mosad Herzl lejeker Hatzionut - Universitat Haifa - Sifriat Po'alim, 1994 (en hebreo).

BÓROJOV, Dov Ber. "Nacionalismo y Lucha de Clases”, José Luis Najenson (Ed., Com.). México, Siglo XXI editores. EN: Cuadernos de pasado y presente. Núm. 83. 1979.

BÓROJOV, Dov Ber. Reflexiones sobre el sionismo. Buenos Aires, E.M.A. Colección Problemas de nuestro tiempo. 1975.

BÓROJOV, Dov Ber. Bases del sionismo socialista. Montevideo, Ediciones Mordejai Anilevich. 1973.

BÓROJOV, Dov Ber. Bases del sionismo proletario. Tel Aviv, Dror-Kibutz Hameujad. 1972.

BÓROJOV, Dov Ber. Clase y nación. Montevideo, Dror. 1969.

BÓROJOV, Dov Ber. Works, L. Levite y Sh. Rehav (Eds.). Tel Aviv, Hakibutz Hameuchad y Siffriath

Poalim. Vol. 3. 1966 (en hebreo).

BÓROJOV, Dov Ber. Works, Daniel Ben Nahum, L. Levite (Eds.). Tel Aviv, Hakibutz Hameuchad y Siffriath Poalim. Vol. 1, 1955; Vol. 2, 1958 (en hebreo).

BÓROJOV, Dov Ber. Su vida y obra. Sionismo. Interpretación científica de la vida judía. Bar Kojba (tr.). Buenos Aires, Biblioteca Borojovista Dror. 1953. 
BÓROJOV, Dov Ber. Nuestra Plataforma. Bases del sionismo proletario. Arié Ben Ami (tr.). Buenos Aires, Editorial "Pueblo judío". 1951.

BÓROJOV, Dov Ber, IAARI, Meir y BEN NAJUM, Daniel. La cuestión nacional. Nación - pueblo, lucha de clases, liberación nacional, antiimperialismo, sionismo, socialismo. Montevideo, Ediciones Mordejai Anilevich. 1968.

EVEN SHOSHÁN, Abraham. Hamilón Haivri Hamerucaz. Jerusalén, Hotza'at Kiriat Sefer. 1993 (en hebreo).

FINKIELKRAUT, Alain. El judío imaginario. Barcelona, Editorial Anagrama. 1982.

FINKIELSZTEJN, Jaime. Ber Borojov. Biblioteca Popular Judía, Congreso Judío Mundial. Buenos Aires, 1968.

FINKIELSZTEJN, Jaime. Der Gaon fon Paltava. Por los 50 años de la muerte de Bórojov. Buenos Aires, Ajdut Avodá - Poalei Tzion. 1967 (en yidish).

FRANKEL, Jonathan. Prophecy and Politics: Socialism, Nationalism and the Russian Jews 1862-1917. Nueva York, Cambridge University Press. 1981.

GREENSTEIN, Ran. "Class, Nation and Polítical Organization: the Anti-Zionist Left in Israel/Palestine", International Labor and Working Class History (75): 85-108, 2009.

GRINFIELD, leraj. “Hajativot hatze'irot hatzioniot-sotzialistiot bearguentina shel shnot hashishim bamea esrim. Havnayat hashkafot 'olam [Las juventudes sionistas socialistas en Argentina durante los años sesenta del siglo XX: la construcción de una concepción de mundo]", tesis de maestría, Universidad Hebrea de Jerusalén, 2006 (en hebreo).

ITZIGSON, José. "Conflictos de identidad judía en América Latina. Aspectos psicológicos", EN: Dispersión y unidad (1): 92-100, 1979.

ITZIGSON, José. "Les juifs en Amerique Latine: processus socio-politiques”, EN: Dispersion et unite (16): 214-216, 1976.

JEROSOLIMSKY, José. “Apuntes sobre la vida de los judíos en el Uruguay”, EN: Comentario (57): 76-83, 1967. 
KOTIC, Meir. The Prague Trial. The first anti-Zionist show trial in the Communist Bloc. Nueva York, Herzl Press. 1987.

LEÓN, Abraham. Concepción marxista de la cuestión judía. Carlos Etkin (Tr. e Intr.). Buenos Aires, Editorial Indoamerica, 1953; Buenos Aires, Editorial Indoamerica, 1965; México D.F., Editora Juan Pablos, 1976.

MACHOVER, Moshé. "Borochovist 'Revival', Left Wing Zionism? EN: Israeli Revolutionary Committee Abroad 4, (3): 27-46, 1971.

MAHLER, Raphael. "Ha-jolef vehakayam bemishnato shel Bórojov [Lo transitorio y lo permanente en los postulados de Bórojov]". EN: GOTHALF, Yehuda (Ed.). Darka Hasotzialit shel Israel [La vía social de Israel], Tel Aviv, Hotza'at Tnu'at Ha'avoda Hatzionit Ha'olamit, 1969. pp. 27-38 (en hebreo).

MAHLER, Raphael. "Economic Foundations of the Jewish People", MAHLER, Raphael, FLAKSER, David y BEN-NAHUM, Daniel (Eds.). EN: Borochov for our Day. The Socialist-Zionist View of the Jewish People. Nueva York, Progressive Zionist League-Hashomer Hatzair, 1958, pp. 31-42.

MARGALIT, Elkana. "Social and Intellectual Origins of the Hashomer Hatzair Movement, 1913-20", EN : Journal of Contemporary History, 4, (2): 25-46, 1969.

MARX, Karl y ENGELS, Friedrich. Sobre la Religión. ASSMANN, Hugo y REYES MATE, Arturo (Eds.). Salamanca, Ediciones Sígueme- 1974.

MARX, Karl y ENGELS, Friedrich. La Sagrada Familia. Wenceslao Roces (Tr.). México, Editorial Grijalbo. 1967.

MINTZ, Matityahu. New Times - New Tunes. Tel Aviv, Am Oved. 1988 (en hebreo).

MINTZ, Matityahu. The Lame and the Nimble. The Story of the "Dror" Group in Russia. Tel Aviv, Hakibbutz Hameuchad, Tel Aviv University y Yad Tabenkin. 1983 (en hebreo).

MINTZ, Matityahu. Ber Borokhov. Circle One (1900-1906). Tel Aviv, Hakibbutz Hameuchad - Tel Aviv University. 1976 (en hebreo).

NAJENSON, José Luis. "Cultura, ideología y nación en América Latina", EN: Revista mexicana de sociología, 43 (2): 728-729, 1981. 
NAHUM, Benjamín. Manual de historia del Uruguay 1903-1990. Vol. II. Montevideo, Editorial Banda Oriental. 1999.

PITIGLIANI, Faurto. "Marx y el antisemitismo marxista”, EN: Tribuna Israelita, 316, 3-14, mayo-junio 1975. PONZA, Pablo. "Comprometidos, orgánicos y expertos: intelectuales, marxismo y ciencias sociales en Argentina (1955-1973)", EN: A contracorriente, 5 (2): 74-98, 2008.

RABINOVICH, losef. El kibutz en Eretz Israel. Advenimiento y desarrollo del Kibutz Hameujad. Bar Kojba Malaj (Tr.). Buenos Aires, Biblioteca Borojovista “Dror”. 1952.

SCHNALL, David, J. "Anti-Zionism, Marxism and Matzpen Ideology and the Israel Socialist Organization", EN: Asian Profile, 6 (4): 381-393, 1978.

SCHWEID, Eliezer. "Aharon David Gordon”, EN: Sillages, 5, 11-22, 1981.

SENKMAN, Leonardo. “La carta de despedida de Bar Kojba Malaj”, EN: Noaj, 10, 103-105, 1995.

SHAPIRA, Avraham. "A. D. Gordon and the Second Aliya. Realization of Utopia". GORNI, Yosef, OVED, Yaacov y PAZ, Idit (Eds.). EN: Communal Life. An International Perspective. Tel Aviv, Yad Tabenkin, Efal, 1987. pp. 130-141.

SZNAJDER, Mario S. "El judaísmo chileno y el gobierno de la unidad popular (1970-1973)", EN: Judaica Latinoamericana, (2): 137-148, 1993.

TURIANSKY, Wladimir. El Uruguay desde la izquierda. Montevideo, Cal y Canto. 1997.

TZUR, Eli. Landscapes of Illusions. Mapam 1948-1954. Beer Sheva, Ben-Gurion University Press. 1998 (en hebreo).

VIDAL-NAQUET, Pierre. Los judíos, la memoria y el presente. México, Fondo de Cultura Económica. 2002.

WHEELER, Marcus y UNBEGAUN, Boris (Eds.). Oxford Russian Dictionary. Oxford, Oxford University Press. 2007.

WISTRICH, Robert S. "El marxismo y el nacionalismo judío: las raíces de la confrontación”, EN: Dispersión y unidad, (16): 114-124, 1975. 
ZAIT, David y SHAMIR, Yosef (Eds.). A Portrait of a Leader as a Young Man. Meir Yaari 1897-1929. Givat Haviva, Yad Yaari. 1992 (en hebreo).

\section{Manuscritos}

BEN NAJUM, Daniel. Manuscritos. Archivo lad la'ari de Guivat Javiva, expediente 16, 55-95.

\section{Entrevistas}

FAIGÓN, Yehoshua, Jerusalén, 18 de febrero de 2009.

MELNICK, Eitan, Jerusalén, 5 de febrero del 2009.

SLOTZKY, Yaron, Jerusalén, 1 de diciembre de 2009.

\section{Publicaciones periódicas}

Bamishlat [Publicación periódica del kibutz Harel del Hashomer Hatza'ir], 18 (65), 5/3/1954.

Compromiso, 1972?

Enfoque. Suplemento teórico de "Nueva Sión", (1): 1962.

La izquierda sionista frente al momento actual: Chile, América Latina, Israel, 1972?

Orot [Luminarias]. Frente de Izquierda Sionista y Hashomer Hatzair Chile, agosto, 1969.

Pregón juvenil, Vocero de la juventud Ber Bórojov, año 1, núm. 1, mayo 1961.

Paz en el Medio Oriente, diciembre, 1968.

Paz en el Medio Oriente y en Vietnam, febrero, 1971. 